
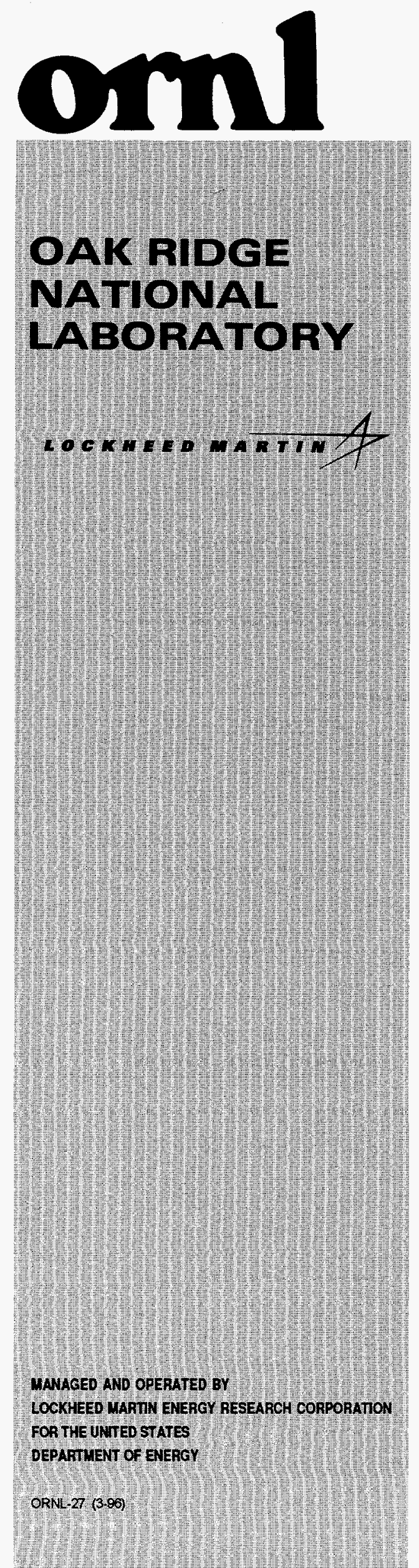

\section{URANIUM SERIES DISEQUILIBRIUM IN THE BARGMANN PROPERTY AREA OF KARNES COUNTY, TEXAS}

BRIUM
Y AREA
XAS

\author{
J. R. Davidson \\ RECEIVED
FFR 191998
OSTI
}

DETRIBUTONON OF THIS DOCUMENT IS UNLIMITED 


\section{DISCLAIMER}

Portions of this document may be illegible electronic image products. Images are produced from the best available original document. 


\title{
URANIUM SERIES DISEQUILIBRIUM IN THE BARGMANN PROPERTY AREA OF KARNES COUNTY, TEXAS
}

\author{
J. R. Davidson
}

Published: February 1998

\author{
Prepared by \\ Oak Ridge National Laboratory \\ Oak Ridge, Tennessee 37831 \\ managed by \\ Lockheed Martin Energy Systems, Inc. \\ for the \\ U. S. Department of Energy \\ under contract No. DE-AC05-96OR22464
}




\section{CONTENTS}

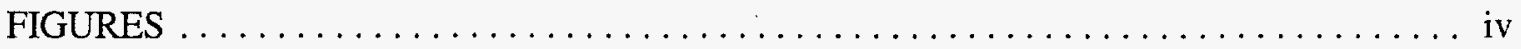

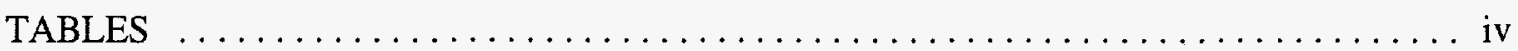

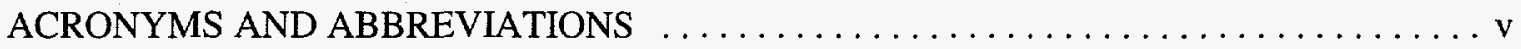

ACKNOWLEDGMENTS $\ldots \ldots \ldots \ldots \ldots \ldots \ldots \ldots \ldots \ldots \ldots \ldots \ldots \ldots$ vi

EXECUTIVE SUMMARY $\ldots \ldots \ldots \ldots \ldots \ldots \ldots \ldots \ldots \ldots \ldots \ldots \ldots \ldots$ vii

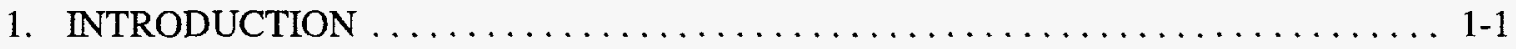

2. EARLY HISTORY OF URANIUM EXPLORATION IN THE BARGMANN PROPERTY

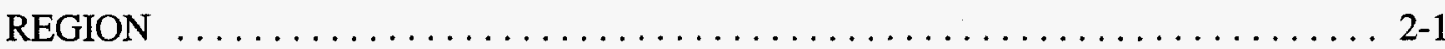

3. NATURAL URANIUM SERIES DISEQUILIBRIUM IN THE BARGMANN PROPERTY REGION PRIOR TO MINING AND MILLING $\ldots \ldots \ldots \ldots \ldots \ldots \ldots \ldots \ldots \ldots . \ldots \ldots$

3.1 The 1955 AEC Report on Uranium Deposits . . . . . . . . . . . . . . . . . 3-1

3.2 The 1958 AEC Report on the Nuhn Lease Deposit $\ldots \ldots \ldots \ldots \ldots \ldots \ldots \ldots$. . . . . . .

4. URANIUM TO RADIUM BACKGROUND RATIOS IN THE BARGMANN PROPERTY

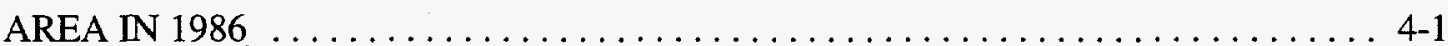

4.1 The Bendix Characterization of the Nuhn Deposit Property ............ 4-1

4.2 Uranium to Radium Background Activity Ratios $\ldots \ldots \ldots \ldots \ldots \ldots . . . \ldots$. . . . . . . .

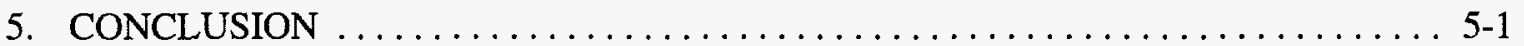

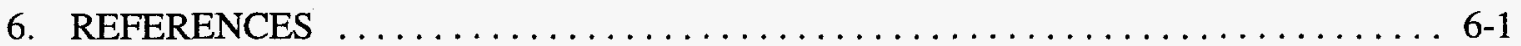

APPENDIX A NATURAL URANIUM SERIES DISEQUILIBRIUM

APPENDIX B URANIUM MASS-TO-ACTIVITY CONVERSION FACTORS FOR SOIL

APPENDIX C DERIVATION OF A CONSTANT TERM IN THE SPECIFIC ACTIVITY EQUATION 


\section{FIGURES}

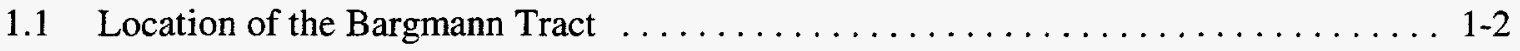

1.2 Bargmann Tract, former mill tailings piles, drainage divide, and area ore deposits . . . 1-3

\section{TABLES}

$4.1{ }^{238} \mathrm{U}$ to ${ }^{226} \mathrm{Ra}$ activity ratios for Bargmann tract area background soil samples . . . . . . 4-1

B.1 Carrier-free specific activities for naturally occurring uranium isotopes $\ldots \ldots \ldots \ldots$ B-2

B.2 Natural abundances of uranium isotopes $\ldots \ldots \ldots \ldots \ldots \ldots \ldots \ldots \ldots \ldots . \ldots \ldots$

B.3 Worksheet for calculating conversion factor using natural abundances $\ldots \ldots \ldots \ldots$ B-3

B.4 Worksheet for calculating conversion factor assuming equilibrium $\ldots \ldots \ldots \ldots \ldots$ B-4 


\section{ACRONYMS AND ABBREVIATIONS}

$\begin{array}{ll}\text { AEC } & \text { U.S. Atomic Energy Commission } \\ \text { DOE } & \text { U.S. Department of Energy } \\ \text { Eq. } & \text { equation } \\ \mathrm{g} & \text { gram } \\ \mathrm{kg} & \text { kilogram } \\ \mu \mathrm{g} & \text { microgram } \\ \mathrm{mg} & \text { milligram } \\ \text { ORNL } & \text { Oak Ridge National Laboratory } \\ \mathrm{pCi} & \text { picocuries } \\ \text { ppm } & \text { parts per million } \\ \text { USGS } & \text { U.S. Geological Survey }\end{array}$




\section{ACKNOWLEDGMENTS}

This project was sponsored by the U.S. Department of Energy under contract DE-AC05-96OR 22464 with Lockheed Martin Energy Corporation. The author would like to acknowledge the following Oak Ridge National Laboratory/Grand Junction, Colorado staff: Doug Halford and John Wilson for valuable technical input and review; Kirk Roemer for timely graphics support; Penny Roundtree for efficient document formatting and preparation support; and Judy Rice, the ORNL Falls City Project Manager, without whose assistance this document would probably not have been produced. 


\section{EXECUTIVE SUMMARY}

Historical evidence is presented for natural uranium series radioactive disequilibrium in uranium bearing soils in the Bargmann property area of Karnes County on the Gulf Coastal Plain of south Texas. The early history of uranium exploration in the area is recounted and records of disequilibrium before milling and mining operations began are given. Activity ratios illustrating disequilibrium between ${ }^{226} \mathrm{Ra}$ and ${ }^{238} \mathrm{U}$ in background soils during 1986 are listed and discussed. Derivations of uranium mass-to-activity conversion factors are covered in detail. 


\section{INTRODUCTION}

The Bargmann property is a 460-hectare (1100-acre) tract in Karnes County, Texas, $1.3 \mathrm{~km}$ (0.8 miles) downstream and southwest of the closed Falls City, Texas, uranium mill (Fig. 1.1). The property contains an open pit uranium mine associated with a larger ore body. In 1995, the U. S. Department of Energy (DOE) directed Oak Ridge National Laboratory (ORNL) to evaluate the Bargmann tract for the presence of uranium mill tailings (ORNL 1996). There was a possibility that mill tailings had washed onto or blown onto the property from the former tailings piles (Fig. 1.2) in quantities that would warrant remediation under the Uranium Mill Tailings Remedial Action Project.

In cases where ore material was known to exist, procedures allowed the analysis of soil to determine the activity ratio of ${ }^{238} \mathrm{U}$ to ${ }^{226} \mathrm{Ra}$. A ratio greater than or equal to 1.0 would indicate naturally occurring radioactive material and a ratio less than 1.0 would indicate mill tailings. When ore samples and formation outcrops on the Bargmann property had ratios of 0.17 and 0.15 , it became clear that equilibrium did not always exist in naturally occurring radioactive material. The question became: Was the disequilibrium found on the Bargmann property due to natural processes or was it due to milling activities? The answer lay in the early history of uranium exploration in the region. See Appendix A for background information on natural uranium series disequilibrium. 


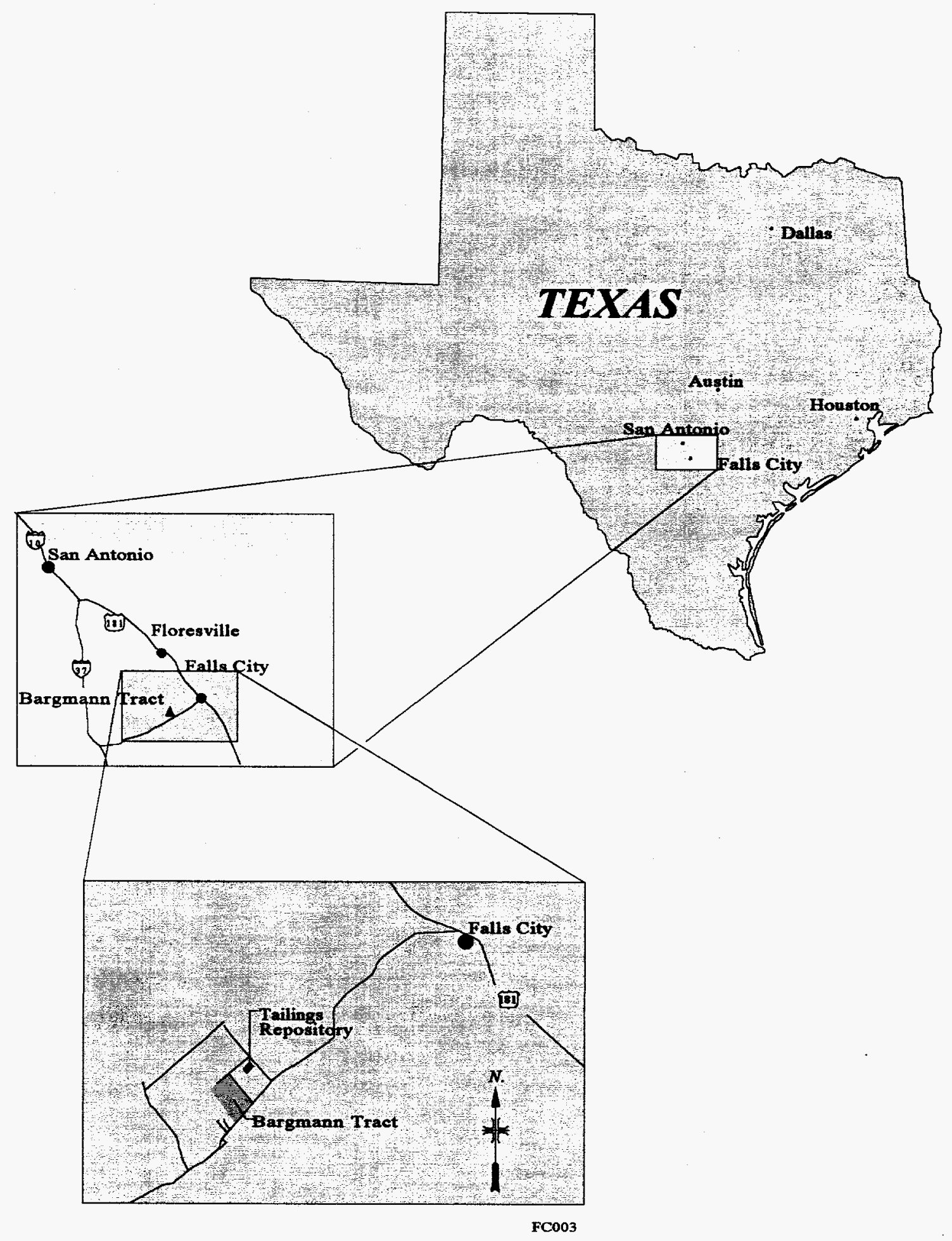

Fig. 1.1. Location of the Bargmann Tract. 


\section{1-3}

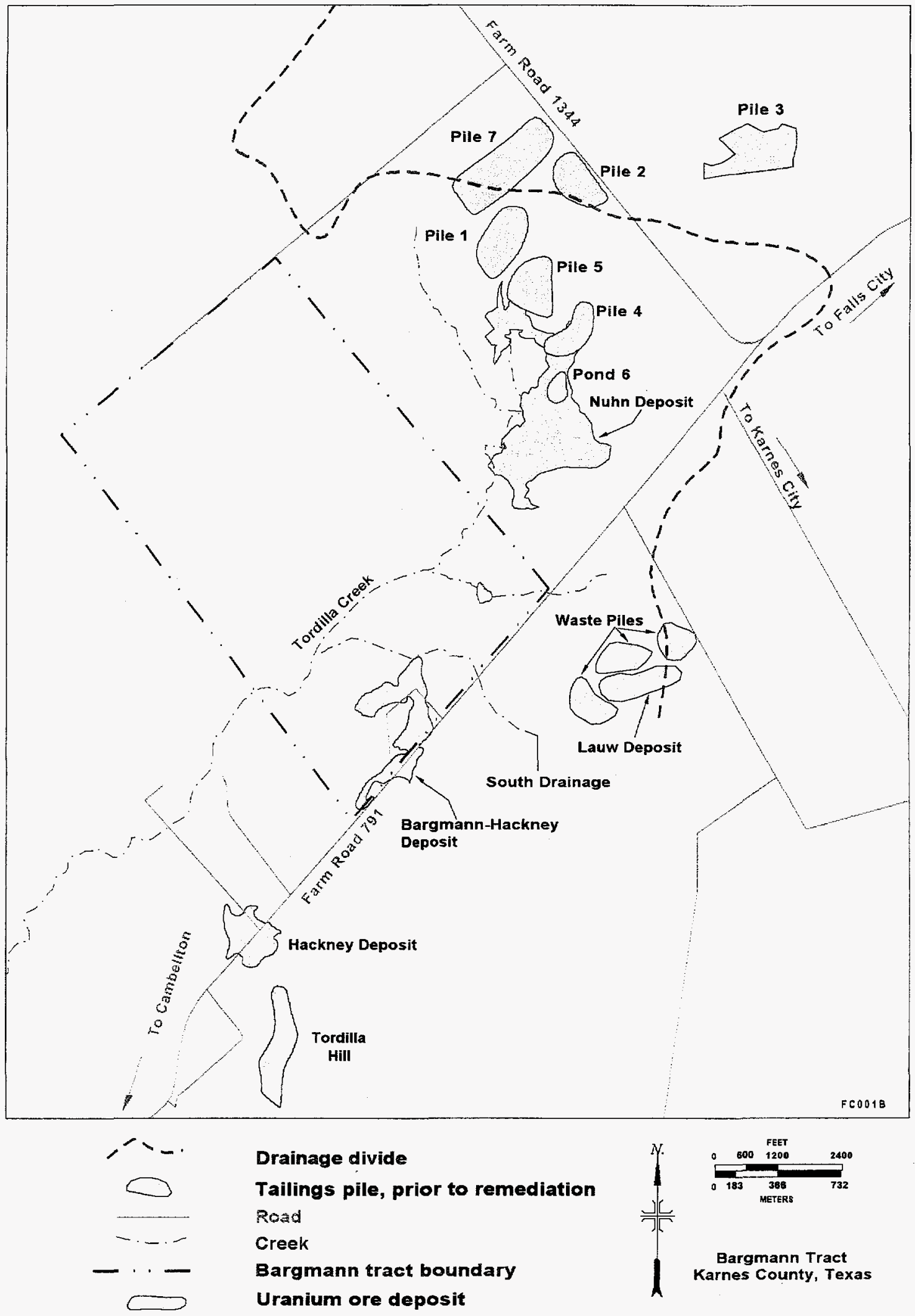

Fig. 1.2. Bargmann Tract, former mill tailings piles, drainage divide, and area ore deposits. 


\section{EARLY HISTORY OF URANIUM EXPLORATION IN THE BARGMANN PROPERTY REGION}

A U. S. Atomic Energy Commission (AEC) report on the uranium geology of the region in which the Bargmann property is located gives the following history (Steinhauser and Beroni 1955, pp. 14, 15):

Radioactivity is reported to have been discovered in the Gulf Coastal Plain region in the fall of 1954, as a result of airborne radiometric reconnaissance for oil structures. The first samples of the uranium-bearing sandstone were brought to the U. S. Atomic Energy Commission in January 1955. The initial discovery was in the upper Fayette sandstone near Tordilla Hill, Karnes County, approximately 9 miles southwest of Falls City. Since that time, numerous other uranium occurrences have been discovered in Karnes, Atascoasa, Gonzales, Live Oak, McMullen, and Duval Counties. Not only have uranium minerals been reported from five stratigraphically different beds of the Fayette sandstone, but they have also been found in the Soledad member of the Catahoula tuff (Gueydan), the basal sandstone of the Caahoula tuff, and the Oakville sandstone.

The following history in reference to the Falls City uranium mill site located near the Bargmann property is given by Marutzky, Knutson, and Colby (1986, pp. 2-5):

Uranium was first discovered in 1954 in southwest Karnes County during a radiometric airborne survey intended to define anomalies over oil fields (Galloway and others, 1979). Mining began in 1960 and Susquehanna-Western, Inc., was the first to build a mill in the area in 1961. The mill began processing 300 tons of ore per day in April of that year, and in 1968 the facilities were expanded to 1,000 tons per day. The mill closed in August 1973 after having processed approximately 2,500,000 tons of ore averaging 0.16 percent $U_{3} \mathrm{O}_{8}$ (Haywood and others, 1980).

A general historical survey given in a U.S. Geological Survey (USGS) report from the 1970s makes clear that no uranium mining or milling was conducted anywhere in the region prior to 1958 (Bunker and Mackallor 1973, p. 20):

In 1958, after the period of intense prospecting but before any mining operations were begun, the U.S. Atomic Energy Commission (S. R. Steinhauser, oral communication, 1958) estimated the reserves of uranium in Karnes, Atascosa, Gonzales Counties, Tex., to be 280,000 tons of ore which would average 0.22 percent $\mathrm{U}_{3} \mathrm{O}_{8}$.

The first production of uranium ore from the southeastern Texas coastal plain was from the Hackney deposit in December 1958, when a few tons of selectively mined ore containing 2.16 percent uranium was trucked to the uranium mill at Grants, N. Mex. 
In July 1959, preparation for open-pit mining was begun by the San Antonio Mining Co. on the Nuhn deposit (Maxwell, 1962, p. 123); and by April 1961, the company had fulfilled its contract to deliver 100,000 tons of ore containing about 0.2 percent $U_{3} O_{8}$. By July 1961, Susquehanna-Western Inc. had mined about 80,000 tons of ore containing about 0.2 percent $U_{3} O_{8}$ from the Luckett deposit (Maxwell, 1962, p. 126). The same company mined the BargmannHackney (formerly Rate Metals) deposit in 1963, greatly enlarged the Korzekwa mine in 1964, and reopened the Hackney deposit and mined about 10,000 tons of ore in 1965 (D. H. Eargle, written commun., 1969). In 1968, production from Susquehanna-Western's mill at Deweesville was about 1.2 million pounds of $U_{3} O_{8}$ (Eargle, 1970).

Based on this history, it appears that uranium series disequilibrium results found prior to 1958 could not have been the result of the mining and milling activities carried on in the late 1950s, $1960 \mathrm{~s}, 1970$ s, or later. Therefore, low ${ }^{238} \mathrm{U}$ to ${ }^{226} \mathrm{Ra}$ activity ratios are not necessarily evidence for the presence of mill tailings on the Bargmann tract. 


\section{NATURAL URANIUM SERIES DISEQUILIBRIUM IN THE BARGMANN PROPERTY REGION PRIOR TO MINING AND MILLING}

\subsection{The 1955 AEC Report on Uranium Deposits}

In November of 1955, S. R. Steinhauser and E. P. Beroni of the AEC reported on studies done in the Gulf Coastal Plain region of Texas where the Bargmann property is located. In fact, the reported airborne reconnaissance of Karnes County was centered on Highway 791. This highway forms the southeastern boundary of the Bargmann property.

The existence of natural uranium series disequilibrium in this area during those pre-mining and pre-milling days is demonstrated by the following statement (Steinhauser and Beroni 1955, p. 14):

The radioactive disequilibrium of the uranium-bearing rocks in the Gulf Coastal Plain region is a very serious problem especially in the evaluation and development of the ore bodies. The relationship of radiometric assays, by total betagamma count, to chemical assays for a large group of samples from the Gulf Coastal Plain region is shown in plate 2. Although it is possible to draw a curve showing mean values, the deviation of individual samples from the mean is sufficient to make radiometric analyses nearly useless, particularly as most of the ore-grade material is in the economically critical range between 0.10 percent and 0.25 percent $\mathrm{cU}_{3} \mathrm{O}_{8}$. In Duval County the problem is further exaggerated by lack of equilibrium even in highly radioactive samples. One specimen from near Freer assayed 2.36 percent $e U_{3} O_{8}$ and 0.062 percent $c U_{3} O_{8}$. Another sample from the same area yielded 5.78 percent $\mathrm{e} \mathrm{U}_{3} \mathrm{O}_{8}$ and 5.32 percent $\mathrm{cU}_{3} \mathrm{O}_{8}$, whereas a sample cut from directly beneath it yielded 0.28 percent $e U_{3} O_{8}$ and 0.024 percent $c U_{3} O_{8}$.

Interpretation of radiometric drill hole logs is practically impossible not only because of the disequilibrium of samples, but also because of the inferred presence of radon and serious contamination within drill holes during drilling. Frequently the radiometric log of a hole will be at complete variance not only with the chemically determined uranium content of the cutting but also with the radioactivity log of the cuttings.

This statement indicates that natural uranium series disequilibrium existed and was a problem for geologists from the very beginning of the south Texas uranium boom. The plate 2 graph mentioned above is titled Disequilibrium of Uranium Bearing Samples from Gulf Coastal Plain Region, Texas. It shows many samples with $\%_{\mathrm{c}} \mathrm{U}$ to $\%_{\mathrm{e}} \mathrm{U}$ ratios well below 1.0 . Some samples have ratios less than 0.1. See Appendix A for a discussion of percent equivalent uranium, $\%_{\mathrm{e}} \mathrm{U}$, and percent chemical uranium, $\%_{c} \mathrm{U}$.

\subsection{The 1958 AEC Report on The Nuhn Lease Deposit}

In 1958, R. G. Hodgens reported on the geology of the Nuhn lease uranium deposit in western Karnes County, Texas. The following statement illustrates that this study was adjacent to the 
Bargmann property (Hodgens 1958, p. 10) (see note regarding spelling):

On the Albert Bargman tract, northeast of Tordilla Hill and adjoining the Nuhn lease on the southwest, a particularly fossiliferous, thin, "coquinid" sandstone of the Falls City shale section contains secondary uranium minerals of non-ore grade.

Since this study was done so close to the Bargmann property, clear evidence of natural uranium series disequilibrium on the Nuhn lease property would provide strong evidence for a similar situation on the Bargmann property next door. Indeed, such evidence is provided in his report (Hodgens 1958, p. 22):

As the ore is mostly in disequilibrium, both radiometrically and chemically, probe and scaler radiometric data were found to be unsatisfactory for use in blocking out the ore....Scaler radiometric and chemical assays of several channel-type samples from the Nuhn Lease deposit are listed below to show typical ranges of disequilibrium of the ore: [ten examples are listed and then this statement is made.]

The disequilibrium prevalent in the deposit suggests that the ore has been subjected to constant transportation and rearrangement by meteoric and ground waters. The primary direction of the movement of the leaching solutions seems to be southward, or generally downdip. The large area of low-grade uranium in the southern part of the deposit...could be a result of such migration of uranium leached from the ore bodies to the north.

This report leaves no question as to the existence of natural uranium series disequilibrium in the Bargmann area.

\section{Note on "Bargmann" property spelling:}

The oldest reference I have found regarding the Bargmann property has the name spelled as "Borgman" in at least one instance (Steinhauser and Beroni 1955, p. 16). A 1958 reference gives the name as Bargman (Hodgens 1958, p. 10). A map in a 1968 reference gives the spelling as "Bargmann" (Corpus Christi Geological Society 1968, p. 0). The very detailed 1973 USGS report gives the name as "Bargmann" at least twice (Bunker and Mackallor 1973, p. 20 and p. 23). I am using "Bargmann" as the preferred spelling in this paper. 


\section{URANIUM TO RADIUM BACKGROUND RATIOS IN THE BARGMANN PROPERTY AREA IN 1986}

\subsection{The Bendix Characterization of the Nuhn Deposit Property}

In 1986, Bendix Field Engineering Corporation did a radiologic characterization of the uranium mill tailings on the Nuhn deposit property adjacent to the Bargmann property on the northeast side. This report also indicates the problem of natural uranium series disequilibrium for this area (Maruktsy, Knutson, and Colby 1986, p. 37):

Soil-sample analyses of the uranium-bearing soils (locations BG-5, -6 , and -9 through -13) indicated Ra-226 concentrations ranging from 4.6 to $275.3 \mathrm{pCi} / \mathrm{g}$, and uranium concentrations from 10 to $79 \mathrm{ppm}$. These values emphasize the disequilibrium between uranium and its daughters....

Determination of the extent of mill-tailings contamination at this site is very difficult due to the presence of uranium-bearing soils on the site. Also, the uranium is not in equilibrium with its daughters, which makes the analytical laboratory results difficult to interpret.

The natural uranium series disequilibrium mentioned above is reflected in the low ${ }^{238} \mathrm{U} /{ }^{226} \mathrm{Ra}$ ratios for background soil samples discussed in the next section.

\subsection{Uranium to Radium Background Activity Ratios}

Background soil samples were taken by Bendix in 1986 near the mill site next to the Bargmann Tract. Table 4-1 gives the results for nine background soil samples taken from uranium-bearing soils and listed in Table H-1 of the Bendix report (Marutzky, Knutson, and Colby 1986, p. H-2).

Table 4.1. ${ }^{238} \mathrm{U}$ to ${ }^{226} \mathrm{Ra}$ activity ratios for Bargmann tract area background soil samples

\begin{tabular}{||c|c|c|c|c|c||}
\hline $\begin{array}{c}\text { Background } \\
\text { location }\end{array}$ & $\begin{array}{c}\text { Depth, } \\
\text { inches }\end{array}$ & $\begin{array}{c}{ }^{226} \mathrm{Ra}, \\
\mathrm{pCi} / \mathrm{g}\end{array}$ & $\begin{array}{c}\mathrm{U}_{\text {total }}, \\
\mathrm{ppm}\end{array}$ & $\begin{array}{c}{ }^{238} \mathrm{U}, \\
\mathrm{pCi} / \mathrm{g} \\
\text { (Using factor 0.334) }\end{array}$ & $\begin{array}{c}{ }^{238} \mathrm{U} \text { to }{ }^{226} \mathrm{Ra} \\
\text { activity ratio }\end{array}$ \\
\hline \hline BKG 5 & 0 & $4.6 \pm 0.5$ & 12 & 4.0 & 0.87 \\
\hline BKG 6 & 0 & $6.4 \pm 0.7$ & 10 & 3.3 & 0.52 \\
\hline BKG 9 & 0 & $7.7 \pm 0.8$ & 13 & 4.3 & 0.56 \\
\hline BKG 10 & 0 & $5.5 \pm 0.6$ & 10 & 3.3 & 0.61 \\
\hline BKG 11 & 0 & $11.6 \pm 1.2$ & 18 & 6.0 & 0.52 \\
\hline BKG 12 & 0 & $9.8 \pm 1.0$ & 17 & 5.7 & 0.58 \\
\hline BKG 13 & 0 & $42.6 \pm 3.9$ & 25 & 8.4 & 0.20 \\
\hline BKG 13 & 6 & $102.5 \pm 9.3$ & 43 & 14.4 & 0.14 \\
\hline BKG 13 & 12 & $275.3 \pm 25.0$ & 79 & 26.4 & 0.10 \\
\hline
\end{tabular}


If the uranium series is in equilibrium, the parent to daughter activity ratios should be close to one. However, if some of the uranium has leached from the soil or the ${ }^{226} \mathrm{Ra}$ concentration has been enhanced, we would expect ratios less than one. The last column of Table 4.1 with heading, ${ }^{238} \mathrm{U}$ to ${ }^{226} \mathrm{Ra}$ activity ratio, shows ratios much less than one and some less than 0.60 .

Although the Bendix report found that "analysis of the tailings materials within the piles indicates that the uranium/radium ratio for 90 percent of these samples is less than 0.60 " (Marutzky, Knutson, and Colby 1986, p. 21), the background ratios above, also include ratios less than 0.60 . Therefore, $\mathrm{a}^{238} \mathrm{U}$ to ${ }^{226} \mathrm{R}$ a ratio less than 0.60 is not conclusive evidence for tailings. In fact, the small ${ }^{238} \mathrm{U}$ to ${ }^{226} \mathrm{Ra}$ ratios above, provide strong evidence for uranium series disequilibrium in these background soils.

The conversion of total uranium in $\mu \mathrm{g}_{\mathrm{u} \text {-Tor }} / \mathrm{g}_{\text {soil }}$ (i.e., $\mathrm{ppm}$ ) to $\mathrm{pCi} \mathrm{U}_{\mathrm{U}-\mathrm{Tot}} / \mathrm{g}_{\text {soil }}$ or $\mathrm{pCi} / \mathrm{g}_{\text {soil }}$ for one of the three uranium isotopes is covered in detail in Appendix B. 


\section{CONCLUSION}

Strong evidence is available showing that natural radioactive disequilibrium for the uranium series existed in the Bargmann property area of Karnes County, Texas, well before mining operations were begun for the AEC in the late 1950s. Therefore, low ${ }^{238} \mathrm{U} /{ }^{226} \mathrm{Ra}$ ratios are not conclusive evidence of mill tailings. What mills do by leaching uranium from the ore can clearly be accomplished by natural processes. 


\section{REFERENCES}

Bunker, C. M., and J. A. Mackallor. 1973. Geology of the Oxidized Uranium Ore Deposits of the Tordilla Hill-Deweesville Area, Karnes County, Texas; A Study of a District Before Mining. Geol. Survey Prof. Paper 765, U. S. Gov. Printing Office, Washington, D. C.

Cember, H. 1983. Introduction to Health Physics. Pergamon Press, New York.

Corpus Christi Geological Society. 1968. 1968 Field Trip South Texas Uranium. Corpus Christi Geological Society, Corpus Christi, Texas.

Firestone, R. B., and V. S. Shirley. 1996. Table of Isotopes, 8th Edition. John Wiley \& Sons, New York.

Hodgens, R. G. 1958. Geology of the Nuhn Lease Uranium Deposit, Western Karnes County, Texas. RME-1085. U. S. Atomic Energy Commission, Grand Junction Operations Office, Production Evaluation Division, Denver Branch, Denver, Colorado.

Ivanovich, M., and R. S. Harmon, eds. 1982. Uranium Series Disequilibrium: Applications to Environmental Problems. Oxford University Press, Oxford.

Marutzky, S. J., S. L. Knutson, and R. Colby. 1986. Radiologic Characterization of the Falls City, Texas, Uranium Mill Tailings Remedial Action Site. GJ-47. Bendix Field Engineering Corporation, Grand Junction, Colorado.

ORNL. 1996. Report of Inclusion Survey at Location FC00031, Bargmann Tract, Karnes County, Texas. Oak Ridge National Laboratory, Grand Junction, Colorado.

Osmond, J. K., and M. Ivanovich. 1992. Uranium-series Disequilibrium: Applications to Earth, Marine, and Environmental Sciences, 2 nd Edition, ed. M Ivanovich and R. S. Harmon. Oxford University Press, Oxford.

Rosholt, J. N., Jr. 1959. Natural Radioactive Disequilibrium of the Uranium Series. U. S. Geol. Survey Bulletin 1084-A, U. S Gov. Printing Office, Washington, D. C.

Scott, J. H., and P. H. Dodd. 1960. Gamma-Only Assaying for Disequilibrium Corrections. RME-135. U. S. Atomic Energy Commission, Grand Junction Operations Office, Production Evaluation Division, Grand Junction, Colorado.

Shleien, B., ed. 1992. The Health Physics and Radiological Health Handbook, Revised Edition. Scinta, Silver Spring, Maryland.

Sill, C. W. 1977. Simultaneous Determination of ${ }^{238} \mathrm{U},{ }^{234} \mathrm{U},{ }^{234} \mathrm{Th},{ }^{226} \mathrm{Ra}$, and ${ }^{210} \mathrm{~Pb}$ in Uranium Ores, Dusts, and Mill Tailings, Health Physics, 33:5 (November).

Steinhauser, S. R., and E. P. Beroni. 1955. Preliminary Report on Uranium Deposits in the Gulf Coastal Plain Region, Southwest Texas. U. S. Atomic Energy Commission, Division of Raw Materials, Denver Exploration Branch, Denver, Colorado. 
APPENDIX A

NATURAL URANIUM SERIES DISEQUILIBRIUM 


\section{APPENDIX A}

\section{NATURAL URANIUM SERIES DISEQUILIBRIUM}

\section{A.1 Natural Decay Series}

Three natural radioactive decay series occur in nature. The ${ }^{238} \mathrm{U}$ isotope of uranium is the parent of fourteen daughter atoms forming the uranium series. This chain is the main concern here. The two other chains are the actinium series headed by the ${ }^{235} U$ isotope and the thorium series headed by the ${ }^{232} \mathrm{Th}$ isotope of thorium. Each of these series begins with a long-lived radioactive isotope of uranium or thorium and ends with a stable isotope of lead.

\section{A.2 The Uranium Series}

The uranium series can be summarized by listing the parent and fourteen daughters in order of decay in two groups (Scott and Dodd 1960, p. 6):

$$
\begin{aligned}
& \text { Uranium Group }
\end{aligned}
$$

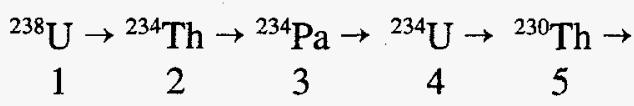

$$
\begin{aligned}
& \text { Radium Group } \\
& { }^{226} \mathrm{Ra} \rightarrow{ }^{222} \mathrm{Rn} \rightarrow{ }^{218} \mathrm{Po} \rightarrow{ }^{214} \mathrm{~Pb} \rightarrow{ }^{214} \mathrm{Bi} \rightarrow{ }^{214} \mathrm{Po} \rightarrow{ }^{210} \mathrm{~Pb} \rightarrow{ }^{210} \mathrm{Bi} \rightarrow{ }^{210} \mathrm{Po} \rightarrow{ }^{206} \mathrm{~Pb} \\
& \text { (stable) } \\
& \begin{array}{llllllllll}
6 & 7 & 8 & 9 & 10 & 11 & 12 & 13 & 14 & 15
\end{array}
\end{aligned}
$$

If this series is in radioactive equilibrium, all the members will have the same activity except the final member ${ }^{206} \mathrm{~Pb}$, which is non-radioactive. Therefore, assuming equilibrium, the ratio of any daughter activity, such as ${ }^{226} \mathrm{Ra}$, to the parent ${ }^{238} \mathrm{U}$ activity will be one. However, if chemical leaching or other processes preferentially remove or enhance the parent or one of the daughters, this ratio will be changed from one to a fraction less than one or to a ratio greater than one such as $1.5,2.0$, or more.

\section{A.3 Evidences of Disequilibrium}

The occurrence of natural disequilibrium in the uranium decay series can be documented by measuring the activity ratio of any two of the radioactive isotopes. However, early indications of this problem were found by comparing the uranium inferred from gamma (or beta-gamma) measurements (assuming radioactive equilibrium) and the actual uranium concentration determined by chemical assay. "When equilibrium exists, about 2 percent of the gamma-ray intensity arises from the uranium group and 98 percent from the radium group" (Scott and Dodd 1960, p. 7). Therefore, when members of the uranium group are leached from the soil, the gamma-ray intensity may change very little even though the uranium concentration is greatly reduced. Note the following statement (Scott and Dodd 1960, p. 7, emphasis added): 


\section{A-2}

Because of the particular physical and chemical characteristics of isotopes in the [uranium] series, disequilibrium commonly exists between two major groups in the decay series, the uranium group and the radium group. Isotopes in the uranium group usually remain in equilibrium with each other, and isotopes in the radium group, unless recently disturbed, usually remain in equilibrium with each other; but disequilibrium commonly exists between the two groups.

The beta activity of the uranium group, when the series is in equilibrium, represents about $40 \%$ of the total (Scott and Dodd 1960, p. 7). Therefore, when the uranium group is preferentially removed from series, the beta-ray intensity will not be reduced in proportion to the actual uranium group loss. The combined result of the differences in gamma-ray and beta-ray proportions in these two groups means that beta-gamma radiation from uranium bearing soils can significantly overestimate the amount of uranium present when uranium group leaching occurs. Two concepts related to this uranium series phenomena (used especially during the 1950 s prospecting era) are percent equivalent uranium, $\%_{\mathrm{e}} \mathrm{U}$, and percent chemical uranium, $\%_{\mathrm{c}} \mathrm{U}$.

The following USGS reference from that time period defines equivalent uranium thus (Rosholt 1959, p. 4):

Equivalent uranium, expressed in percent $e U$, is the ratio of the radioactivity of the sample to the radioactivity of a uranium-ore standard which is in equilibrium with all of its decay products.

Chemical uranium is simply the amount of uranium actually measured by chemical assay. (Note that some authors denote equivalent uranium or chemical uranium as percent uranium oxide.) Therefore, if the radiometrically determined equivalent uranium is $0.10 \% \mathrm{e}_{3} \mathrm{O}_{8}$ and the chemical assay is $0.05 \%{ }_{\mathrm{c}} \mathrm{U}_{3} \mathrm{O}_{8}$, the disequilibrium of the uranium group to the radium group is 0.05 to 0.10 , which is $1 / 2$.

It should be noted, that a number of studies have indicated that even the uranium members of the uranium group, i.e., ${ }^{238} \mathrm{U}$ and ${ }^{234} \mathrm{U}$, though they are the same element can also be out of radioactive equilibrium with each other (Sill 1977, pp. 400, 401):

Other than in the Uravan and pitchblende samples, uranium is generally depleted in ${ }^{234} U$, the ores and dusts from Gas Hills being somewhat more so than those from Shirley basin. These data are consistent with the 7-22\% deficiencies found by Rosholt et al. (Ro64) in ore sands from Shirley basin. In the present authors' opinion, the most likely explanation is that relatively more of the ${ }^{234} U$ produced in situ by radioactive decay of the ${ }^{238} U$ is in the hexavalent oxidation state compared to the ${ }^{238} U$. In marked contrast to the quadrivalent state, hexavalent uranium is known to form very stable and water-soluble complexes with carbonates which are generally present in ground waters in high concentrations and will be selectively leached at a much faster rate. This explanation is supported by the fact that uranium present in ground water is known to be enriched in ${ }^{234} U$ sometimes by as much as $1300 \%$ relative to the ${ }^{238} U$. 
In general, the evidence for natural uranium series disequilibrium is plentiful. A reference dealing with this wide-spread phenomenon is Uranium Series Disequilibrium: Applications to Environmental Problems (Ivanovich and Harmon 1982). A second edition has also been published (Osmond and Ivanovich 1992). Material from the concluding remarks of a chapter dealing with disequilibrium and exploration for uranium is given below (Ivanovich and Harmon 1982, pp. 381 to 382 ):

In exploration for $U$ ores disequilibrium can often result in many difficult and frustrating situations as some of the examples presented in the above discussions have shown. However, it is well worth emphasizing that disequilibrium must not be viewed only in a negative light. The following points, if thoroughly understood, can result in disequilibrium being turned into an advantage during exploration.

In the search for $U$ ore deposits, it must be recognized that a multi-element (for example, $U, R a, R n)$ system is involved. Each element in the $U$ decay series has its own chemical and physical properties which may result in different mobilities, different sampling media being used, and different detection methods (for example, gamma or alpha detectors) being required. Certain nuclides (for example, ${ }^{234} U,{ }^{226} R a,{ }^{222} R n$ ), have significant chemical mobility under specific environmental conditions and these nuclides may be considered as pathfinders in such environments. 
APPENDIX B

URANIUM MASS-TO-ACTIVITY CONVERSION FACTORS FOR SOIL 


\section{APPENDIX B \\ URANIUM MASS-TO-ACTIVITY CONVERSION FACTORS FOR SOIL}

\section{B.1 Introduction}

Uranium occurs naturally in soil as three isotopes: ${ }^{234} \mathrm{U},{ }^{235} \mathrm{U}$, and ${ }^{238} \mathrm{U}$. If a chemical analysis reports only total uranium in $\mu \mathrm{g} / \mathrm{g}_{\text {soil }}$ (or equivalently $\mathrm{mg} / \mathrm{kg}_{\text {soil }}$, both are $\mathrm{ppm}$ ), calculations must be made to estimate the activity of any specific uranium isotope and the total uranium activity. The purpose of this paper is to provide documented conversion factors based on the latest halflife and other required input data.

The recommended conversion factors from $\mu \mathrm{g}_{\mathrm{U}-\mathrm{Tol}} / \mathrm{g}_{\text {soil }}$ to $\mathrm{pCi}_{\mathrm{U}-\mathrm{Tol}} / \mathrm{g}_{\text {soil }}$ are given below:

0.683 when radioactive equilibrium (secular) is assumed, and

0.690 when natural abundances are assumed.

In practice, either of these factors will provide essentially the same answer.

Section B.2 establishes the soil-free specific activity for each uranium isotope. Section B.3 provides a $\mu \mathrm{g} / \mathrm{g}$ to $\mathrm{pCi} / \mathrm{g}$ conversion factor for total uranium activity when "typical" natural uranium abundances for the three isotopes are assumed. Section B.4 provides a $\mu \mathrm{g} / \mathrm{g}$ to $\mathrm{pCi} / \mathrm{g}$ conversion factor for total uranium activity when radioactive equilibrium between ${ }^{238} \mathrm{U}$ and ${ }^{234} \mathrm{U}$ is assumed. Section B.5 briefly discusses the situation where no assumption is made regarding typical isotopic abundances or radioactive equilibrium. Section B.6 summarizes the results and discusses limitations to the use of the conversion factors. The appendix provides the derivation of a constant term in the specific activity equation used to calculate conversion factors.

Note that $\mu \mathrm{g}_{\mathrm{U} \text {-Tol }} / \mathrm{g}_{\text {soil }}$ is equivalent to $\mathrm{mg} \mathrm{U}$-Tor $/ \mathrm{kg}_{\text {soil }}$ since multiplication of $\mu \mathrm{g}_{\mathrm{U} \text {-Tol }} / \mathrm{g}_{\text {soil }}$ by $1,000 / 1,000$ yields $\mathrm{mg}_{\text {U-Tol }} / \mathrm{kg}_{\text {soill }}$. This can also be seen by dividing out the gram units to get in both cases $10^{-6}$, i.e., ppm.

\section{B.2 Soil-free Specific Activity for Each Isotope}

The purpose of this section is to calculate the specific activity of each uranium isotope in pure form. These calculated values ultimately depend on an accurate half-life value for each isotope and Avogadro's constant.

The soil-free specific activities of the natural uranium isotopes can be calculated in $\mathrm{pCi} / \mathrm{g}$ by modifying Eq. (3) of The Health Physics and Radiological Health Handbook (Shleien 1992, p. 264). This equation is

$$
S A=\frac{4.17 \times 10^{23}}{A \times T_{1 / 2}} \frac{\mathrm{Bq}}{\mathrm{g}}
$$


where

$S A \quad$ is the specific activity of the pure isotope in $\mathrm{Bq} / \mathrm{g}$,

4.17 is actually 4.174227 and depends on Avogadro's number as shown in Appendix C,

$A$ is the atomic weight of the isotope,

$T_{1 / 2} \quad$ is the half-life of the isotope in seconds.

The definition of a curie is, $1.0 \mathrm{Ci}=3.7 \times 10^{10} \mathrm{~Bq}$, therefore, $1.0 \mathrm{pCi}=3.7 \times 10^{-2} \mathrm{~Bq}$. Thus, Eq. (B1) can be written

$$
S A=\frac{4.174227 \times 10^{23}}{A \times T_{1 / 2}} \frac{\mathrm{Bq}}{\mathrm{g}} \times \frac{1.0 \mathrm{pCi}}{3.7 \times 10^{-2} \mathrm{~Bq}}=\frac{1.1282 \times 10^{25} \mathrm{pCi}}{A \times T_{1 / 2}} \frac{\mathrm{g}}{.}
$$

Table B.1 below lists the soil-free specific activity for each isotope based on Eq. (B2). The halflife values are from Table of Isotopes (Firestone and Shirley 1996).

Table B.1. Soil-free specific activities for naturally occurring uranium isotopes

\begin{tabular}{||c|c|c|c|}
\hline Isotope & Half-life, years & Half-life, seconds & Specific activity, pCi/g \\
\hline \hline${ }^{234} \mathrm{U}$ & $2.468 \times 10^{5}$ & $7.78825 \times 10^{12}$ & $6.1906 \times 10^{9}$ \\
\hline${ }^{235} \mathrm{U}$ & $7.038 \times 10^{8}$ & $2.22098 \times 10^{16}$ & $2.1616 \times 10^{6}$ \\
\hline${ }^{238} \mathrm{U}$ & $4.468 \times 10^{9}$ & $1.40996 \times 10^{17}$ & $3.3620 \times 10^{5}$ \\
\hline
\end{tabular}

Years to seconds conversion used:

$$
1.0 \mathrm{y}=3.155692 \times 10^{7} \mathrm{~s} \text { (Firestone and Shirley 1996, p. B-2). }
$$

\section{B.3 Conversion Factors Based on Typical Isotopic Abundances}

To calculate specific activities for soil, the relative abundances of the isotopes must be known or estimated. Typical natural abundances of uranium isotopes are given below in Table B.2 (Firestone and Shirley 1996):

Table B.2. Natural abundances of uranium isotopes

\begin{tabular}{|c|c|}
\hline Uranium isotope & Natural abundance, \% \\
\hline \hline${ }^{234} \mathrm{U}$ & 0.0055 \\
\hline${ }^{235} \mathrm{U}$ & 0.7200 \\
\hline${ }^{238} \mathrm{U}$ & 99.2745 \\
\hline
\end{tabular}


Each calculation in the Table B.3 worksheet below starts with a soil sample with total uranium concentration of one $\mu \mathrm{g}_{\mathrm{U}-\mathrm{to}} / \mathrm{g}_{\text {soil }}$ (i.e., one ppm total uranium). This total uranium concentration is then multiplied by the typical natural abundance of the isotope. The resulting product is next multiplied by the soil-free specific activity of the isotope. The calculated value in bold type is the specific activity in soil for each isotope. The assumption that the typical natural abundances of the isotopes are correct for a given soil sample is critical to this calculation.

Table B.3. Worksheet for calculating conversion factor using natural abundances

Specific Activity of ${ }^{234} \mathrm{U}$ for $1.0 \mu \mathrm{g} U$-tot per gram of soil:

$$
\frac{10^{-6} \mathrm{~g}_{\mathrm{U}-\mathrm{tot}}}{\mathrm{g}_{\text {soil }}} \times \frac{0.000055 \mathrm{~g}_{\mathrm{U}-234}}{\mathrm{~g}_{\mathrm{U} \text {-tot }}} \times \frac{6.1906 \times 10^{9} \mathrm{pCi}_{\mathrm{U}-234}}{\mathrm{~g}_{\mathrm{U}-234}}=\frac{\mathbf{0 . 3 4 0 5} \mathbf{p C \mathbf { i } _ { \mathbf { U } - 2 3 4 }}}{\mathrm{g}_{\text {soil }}}
$$

Specific Activity of ${ }^{235} \mathrm{U}$ for $1.0 \mu \mathrm{g}$-tot per gram of soil:

$$
\frac{10^{-6} \mathrm{~g}_{\mathrm{U}-\text { tot }}}{\mathrm{g}_{\text {soil }}} \times \frac{0.007200 \mathrm{~g}_{\mathrm{U}-235}}{\mathrm{~g}_{\mathrm{U} \text {-tot }}} \times \frac{2.1616 \times 10^{6} \mathrm{pCi}_{\mathrm{U}-235}}{\mathrm{~g}_{\mathrm{U}-235}}=\frac{\mathbf{0 . 0 1 5 6} \mathbf{p C \mathbf { i } _ { \mathbf { U } - 2 3 5 }}}{\mathbf{g}_{\text {soil }}}
$$

Specific Activity of ${ }^{238} \mathrm{U}$ for $1.0 \mu \mathrm{g}$ U-tot per gram of soil:

$$
\frac{10^{-6} \mathrm{~g}_{\mathrm{U} \text {-tot }}}{\mathrm{g}_{\text {soil }}} \times \frac{0.992745 \mathrm{~g}_{\mathrm{U}-238}}{\mathrm{~g}_{\mathrm{U}-\text { tot }}} \times \frac{3.3620 \times 10^{5} \mathrm{pCi}_{\mathrm{U}-238}}{\mathrm{~g}_{\mathrm{U}-235}}=\frac{\mathbf{0 . 3 3 3 8} \mathbf{p C \mathbf { i } _ { \mathbf { U } - 2 3 8 }}}{\mathbf{g}_{\text {soil }}}
$$

$$
\text { Total Activity of Uranium Isotopes for } 1 \mu \mathrm{g} U-\mathrm{tot} / \mathrm{g}_{\text {soil }}=\frac{0.690 \mathrm{pCi}_{\mathrm{U} \text {-tot }}}{\mathrm{g}_{\text {soil }}}
$$

Note: The intermediate results in bold type were rounded at the fourth place to the right of the decimal. While this number of significant digits may not be justified by the precision of the input data, these figures are retained as intermediate factors to be used to calculate a final result.

The total uranium mass-to-activity conversion factor based on the above calculations and with the appropriate units is $0.690 \mathbf{~ p C i}_{\text {U-Tot }} / \mu_{\mathrm{U} \text {-Tot }}$. An example calculation for soil with $12 \mu \mathrm{g}$ U-tot $\mathrm{g}_{\text {soil }}$ follows:

$$
12 \mu \mathrm{g}_{\mathrm{U} \text {-tot }} / \mathrm{g}_{\text {soil }} \times 0.690 \mathrm{pCi}_{\mathrm{U}-\mathrm{Tot}} / \mu \mathrm{g}_{\mathrm{U} \text {-Tot }}=8.28 \mathrm{pCi}_{\mathrm{U}-\mathrm{Tot}} / \mathrm{g}_{\text {soil }} \text {. }
$$

Similar calculations can be made for the individual isotopes (e.g., use $0.3338 \mathrm{pCi}_{\mathrm{U}-238} / \mu \mathrm{g}_{\mathrm{U}-\mathrm{Tot}}$ to calculate ${ }^{238} \mathrm{U}$ activity from total uranium given in $\left.\mu \mathrm{g}_{\mathrm{U} \text {-tor }} / \mathrm{g}_{\text {soil }}\right)$. 


\section{B.4 Conversion Factors Based on Radioactive Equilibrium}

If we assume ${ }^{234} \mathrm{U}$ activity in soil is in radioactive equilibrium with ${ }^{238} \mathrm{U}$ activity, the factors given in Sect. B.3 should be adjusted slightly. The ${ }^{234} \mathrm{U}$ factor is larger than the ${ }^{238} \mathrm{U}$ factor, probably due to averaging various isotopic abundance data sets. Assuming radioactive equilibrium, the ${ }^{234} \mathrm{U}$ factor should be the same as the ${ }^{238} \mathrm{U}$ factor. Therefore, the factors to be used are changed to those given in Table B.4 given below.

Table B.4 Worksheet for calculating conversion factor assuming equilibrium

Specific Activity of ${ }^{234} \mathrm{U}$ for $1.0 \mu \mathrm{g} U$-tot per gram of soil $=\frac{0.3338 \mathbf{p C i}_{\mathrm{U}-234}}{\mathrm{~g}_{\text {soil }}}$

Specific Activity of ${ }^{235} \mathrm{U}$ for $1.0 \mu \mathrm{g} U$-tot per gram of soil $=\frac{0.0156 \mathrm{pCi}_{\mathrm{U}-235}}{\mathrm{~g}_{\text {soil }}}$

Specific Activity of ${ }^{238} \mathrm{U}$ for $1.0 \mu \mathrm{g}$-tot per gram of soil $=\frac{0.3338 \mathrm{pCi}_{\mathrm{U}-238}}{\mathrm{~g}_{\text {soil }}}$

Total Activity of Uranium Isotopes for $1 \mu \mathrm{g} U-\operatorname{tot} / \mathrm{g}_{\text {soil }}=\frac{0.683 \mathrm{pCi}_{\mathrm{U}-\text { tot }}}{\mathrm{g}_{\text {soil }}}$

Note that since ${ }^{235} \mathrm{U}$ is not in the uranium series (it is in the actinium series) the assumption of equilibrium does not apply in its case.

The total uranium mass-to-activity conversion factor based on the above calculations and with the appropriate units is $0.683 \mathbf{p C i}_{\mathrm{U} \text {-Tor }} / \mathrm{\mu g}_{\mathrm{U} \text {-Tot }}$. An example calculation for soil with $12 \mu \mathrm{g} \mathrm{U}$-tot $\mathrm{g}_{\text {soil }}$ follows:

$$
12 \mu \mathrm{g}_{\mathrm{U}-\text { tot }} / \mathrm{g}_{\text {soil }} \times 0.683 \mathrm{pCi}_{\mathrm{U}-\mathrm{Tot}} / \mu \mathrm{g}_{\mathrm{U}-\mathrm{Tot}}=8.20 \mathrm{pCi}_{\mathrm{U}-\mathrm{Tot}} / \mathrm{g}_{\text {soil }} \cdot
$$

Note that the assumption of radioactive equilibrium produces a slightly smaller answer than the previous result of $8.28 \mathrm{pCi}_{\mathrm{U}-\mathrm{Tot}} / \mathrm{g}_{\text {soil }}$. This is because the natural abundance data for ${ }^{234} \mathrm{U}$ given in the previous section lists a larger ${ }^{234} \mathrm{U}$ value than that implied by radioactive equilibrium.

The conversion factors given in this and the last section differ by about one percent. This is a minor problem from an environmental standpoint and the use of either conversion factor will typically yield essentially equivalent answers. The much more serious problem of uraniumseries disequilibrium is discussed in the next section. 


\section{B.5 Calculations When Disequilibrium Is Suspected}

It is known that ${ }^{234} \mathrm{U}$ need not be in equilibrium with ${ }^{238} \mathrm{U}$ in either soil or groundwater (Sill 1977; Osmond and Ivanovich 1992). If we do not wish to assume radioactive equilibrium between ${ }^{234} \mathrm{U}$ and ${ }^{238} \mathrm{U}$ isotopes, a site-specific set of conversion factors could be obtained. A second option would be to do isotopic analysis for each uranium isotope in all soil samples needed for the site. A third option, driven by analysis cost, would be to assume that radioactive equilibrium is a conservative assumption for the site and use the factors in Sect. B.4. For example, if ${ }^{234} \mathrm{U}$ has been selectively leached from the soil the factors in Sect. B.4 will lead to an overestimate of total uranium soil activity.

\section{B.6 Summary and Limitations}

When radioactive equilibrium is assumed between ${ }^{234} \mathrm{U}$ and ${ }^{238} \mathrm{U}$, use the $0.683 \mathrm{pCi}_{\mathrm{U} \text {-Tol }} / \mathrm{\mu g}_{\mathrm{U} \text {-Tot }}$ conversion factor to obtain total uranium activity. When typical natural abundances of the uranium isotopes are assumed, use the $0.690 \mathrm{pCi}_{\mathrm{U}-\mathrm{Tol}} / \mu \mathrm{g}_{\mathrm{U}-\mathrm{Tot}}$ conversion factor.

If the three uranium isotopes always occurred in the natural abundances given in Sect. B.2, the conversion factors given there could be used with confidence. Also, if the ${ }^{234} \mathrm{U}$ and ${ }^{238} \mathrm{U}$ isotopes were always in radioactive equilibrium, the factors given in Sect. B. 3 could be used with confidence. However, the user of these conversion factors should be aware that significant variations in ${ }^{234} \mathrm{U}$ to ${ }^{238} \mathrm{U}$ activity ratios can occur when groundwater leaching is present. For example, the leaching process can reduce the ${ }^{234} \mathrm{U}$ uranium activity compared to equilibrium conditions. The basis for this phenomenon is given below (Osmond and Ivanovich 1992, p. 286):

During normal weathering processes, ${ }^{234} \mathrm{U}$ is more mobile than its parent, ${ }^{238} \mathrm{U}$. Ground waters and surface drainage waters generally have a high ${ }^{234} U /^{238} U$ activity ratio, whereas the residual soils tend to have a low activity ratio.

Whether uranium leaching is a significant problem must be determined on a site-specific basis. 
APPENDIX C

DERIVATION OF A CONSTANT TERM IN THE SPECIFIC ACTIVITY EQUATION 


\section{APPENDIX C}

\section{DERIVATION OF A CONSTANT TERM IN THE SPECIFIC ACTIVITY EQUATION}

Equation (B2) of this document is used to calculate all soil-free specific activities given in Sect. B.2. It is, in turn, based on Eq. (3) from The Health Physics and Radiological Health Handbook (Shleien 1992, p. 264). The development of that equation is taken from Cember (1983, p. 77). However, these two references differ at the third significant digit in the constant term of their respective equations. The Shleien equation is

$$
S A=\frac{4.17 \times 10^{23}}{A \times T} \frac{\mathrm{Bq}}{\mathrm{g}}
$$

while the Cember equation is

$$
S A=\frac{4.18 \times 10^{23}}{A \times T} \frac{\mathrm{Bq}}{\mathrm{g}}
$$

The purpose of this appendix is to derive this constant term for use in our calculations. These two references use different values for the Avogadro constant, $N_{\mathrm{A}}$, in their derivations; this probably explains the difference in the factors shown above.

Specific activity is defined to be activity per unit weight (Shleien 1992). The basic equation used to quantify this concept is

$$
S A=\lambda N=\frac{\lambda N_{A}}{A} \frac{\mathrm{Bq}}{\mathrm{g}}
$$

where

$\lambda$ is the transformation (decay) constant of the isotope,

$N_{\mathrm{A}}$ is the Avogadro constant, and

$A$ is the atomic weight of the isotope.

It is often easier to obtain the half-life of an isotope rather than the decay constant $\lambda$. We will use a well-known relation between half-life and $\lambda$ to modify Eq. (C3). This relation is

$$
\lambda=\frac{\ln 2}{T_{1 / 2}}
$$




\section{C-2}

where

$\lambda$ is the transformation (decay) constant of the isotope,

$\ln 2$ is the natural logarithm of 2 , and

$T_{1 / 2}$ is the half-life of the isotope.

The best available value for $N_{\mathrm{A}}$ is $6.0221367 \times 10^{23}$ (Firestone and Shirley 1996, p. B-1). Substituting these values into Eq. (C3) results in

$$
S A=\frac{\ln 2 \times 6.0221367 \times 10^{23} \mathrm{~Bq}}{A \times T_{1 / 2}}=\frac{4.174227 \times 10^{23} \mathrm{~Bq}}{A \times T_{1 / 2}} .
$$

The constant term in Eq. (C5), $4.174227 \times 10^{23}$, is used in this document. 


\section{INTERNAL DISTRIBUTION}

1. B. A. Berven

2. B. Coleman

3 - 7. J. R. Davidson

8. P. V. Egidi

9. A. D. Laase

10 - 15. C. A. Little

16. D. K. Halford

17. G. H. Forbes
18. G. A. Pierce

19. J. A. Rice

20. J. E. Wilson

21. Central Research Library

22 - 23. Laboratory Records

24. Laboratory Records - RC

25. ORNL Patent Section

26. ORNL Technical Library, Y-12

\section{EXTERNAL DISTRIBUTION}

27. Martin Brennon, Jacobs Engineering Group, 2155 Louisiana, N.E., Suite 10,000, Albuquerque, New Mexico 97110.

28. Robert Cornish, Albuquerque Operations Office/ERD, P.O. Box 5400, Albuquerque, New Mexico 87185-5400.

29. Catherine Kelleher, MACTEC-ERS, 2597 B33/4 Road, Grand Junction, Colorado 81503.

30. Jeffrey W. Lively, MACTEC-ERS, 2597 B3/4 Road, Grand Junction, Colorado 81503.

31. Bob Morritz, Safe Sites of Colorado/RFETS, P.O. Box 464, Building 112, Golden, Colorado 80402.

32. L. A. Woodworth, Albuquerque Operations Office/ERD, P.O. Box 5400, Albuquerque, New Mexico 87185-5400.

33. Office of Assistant Manager, Energy Research and Development, Oak Ridge Operations Office, P.O. Box 2001, Oak Ridge, TN 37831-8600

34 - 35. Office of Scientific and Technical Information, U.S. Department of Energy, P.O. Box 62, Oak Ridge, TN 37831 